Karolina Wojtasik

University of Silesia (Poland)

\title{
How and Why Do Terrorist Organizations Use the Internet?
}

\begin{abstract}
The article gives general characterisation of the ways in which these organizations use modern communication technologies. Currently, every major terrorist organisation maintain robust media wings, which focus on producing videos, publishing magazines and sharing them with the public via the Web. The empirical system of reference is based on the activity of al-Qaeda, her franchise AQAP (al-Qaeda in the Arabian Peninsula) and ISIS (the so-called Islamic State). While analysing the media of terrorist organisations, the Lasswell model was applied. This formula is a standard research procedure used for investigating acts of communication by answering the questions: who, says what, in which channel, to whom, with what effect?. The author also present typology of videos produced by jihadist organisations, characterised the most important and active media actions of terrorist organisations and a typology of recipients of such messages. The article presents a number of reasons why the Internet has become such an important tool for terrorists
\end{abstract}

Keywords: ISIS; al-Qaeda; AQAP; terrorist propaganda; terrorist media, Cyber Terrorism

\section{Introduction}

The effectiveness of terrorist activity depends on its scale. More spectacular and severe actions have a better chance to realise the political and strategic goals of terrorist groups. It should be underlined that terrorists have always been dependent on the media which showed, quoted and, so to speak, mediated in spreading fear. However, for years terrorist organisations did not have any impact on the content and quality of the broadcasted communiqués. Currently, terrorist groups have their own media 
wings, periodicals, editors and camera operators. The Internet and modern technology has allowed terrorist groups to disseminate content which they can fully control.

VHS cassettes containing instructions on bomb assembly, recruitment propaganda or recordings of leader speeches were already used for propaganda and instructional purposes during the Soviet-Afghan War (1979-1989), long before the emergence of the so-called Islamic State. However, these materials were prepared in Arabic or languages used in Afghanistan (e.g. Pashto, Dari), thus were available only to a limited group of people. Also, due to the lack of distribution possibilities provided by the Internet, these publications were received only by the people directly involved in combat. Nowadays, terrorist organisations reach fighters from the West who have undergone radicalisation (children of Muslim immigrants or people with European passports who converted to Islam), been inspired by the so-called lone wolves and radicalise people who often do not know Arabic - thus there is a need to prepare materials in English. Numerous publications available online promote radicalisation, show methods of operation, provide practical guidelines and inspire action. Films produced by terrorist organisations play a similar function. Radical online leaders have become as dangerous as the mujahideen).

The aim of this article is to characterise some aspects of the use of the Internet in the activities of terrorist organisations and to attempt to analyse this phenomenon. The authors focus on creation and distribution of the publications of terrorist organisations and present how these materials spread fear and introduce an atmosphere of anxiety. A number of threads related to the presence of terrorists in the media and medial image of terrorism was omitted because these topics are raised in publications from the fields of security, media and social communication (Białek, 2005; Goban-Klas, 2009; Liedel, 2006), whereas the media of terrorist organisations aren't popular area of research.

An in-depth study analysed various materials - publications of terrorist organisations (magazines, films, music, posters, books) officially made available by organisations such as al-Qaeda, AQAP (al-Qaeda in the Arabian Peninsula) and ISIS (the so-called

1 Al-Qaeda in the Arabian Peninsula (AQAP) - Islamist militant organization, which is active in Yemen and Saudi Arabia (but also inspires and gives guidance how to prepare a terrorist attack to volunteers all over the world), considered the most active and dangerous of al-Qaeda's branches. AQAP is responsible for numerous attacks and acts of terror in Jemen and Saudi Arabia, as well as for the attack on the offices of satirical weekly newspaper Charlie Hebdo in Paris in January 2015.

Islamic State (IS) - Salafi jihadist militant group, which proclaimed unrecognized quasi-state on the occupied territories in Iraq and Syria. Organization or organization's followers execute terrorist attacks all over the world (also in EU and USA). Various governments and Muslim groups rejecting its statehood that's why abbreviation ISIS/ISIL (Islamic State of Iraq and Syria (Sham)/ 
Islamic State). The above organisations were selected due to their high media activity and professionalism in production. The aim of the study is a general characterisation of ways in which these organisations use modern communication technologies.

The theoretical system of reference is based on social communication theories and terminology related to communication science. The official media of terrorist organisations are part of the mass media - means of mass communication which are public communication channels characterised by having an institutional communicator, collective transmission multiplexed by technical means and heterogeneous, and an unstructured community of anonymous recipients (Pisarek, 2008, p. 121). However, it should be noted that these media types are specific - the messages are produced by terrorist organisations and are strongly marked by ideology and the propaganda of the organisation. While analysing the media of terrorist organisations, a formula of research procedure was applied used for investigating acts of communication called the Lasswell model. It was chosen particularly because it includes the effects of an act of communication (Pisarek, 2008, p. 109-110) which is very important from the point of view of the subject matter in question. The Lasswell's model of communication was developed by American communication theorist and introduced in 1948 in article The Structure and Function of Communication in Society. It is regarded one of the earliest conceptual models used to explain human communication processes. According to Harold D. Lasswell the best way to describe the act of communication is to answer the following questions: who? says what? in which channel? to whom? with what effect? In this model, the communication component who refers communicator, says what refers to the type of message, in which channel refers to the medium, to whom refers to audience and with what effect refers to effect of an act of communication. This model has a lot of advantages: it is simple and easy, it suits for almost all types of communication and takes into consideration the concept of effect, but also is criticized: it's linear model, it doesn't mention feedback and noise.

\section{Who is Talking?}

Terrorist organisations are not random, chaotic groups of unstable sociopaths. Such a stereotypical image, which is still prevelant in public opinion, is untrue and detrimental from the point of view of preventive action. Terrorist groups usually have

Levant) is commonly used as it was the official name of the organization between 2013-2014. There is also used an acronym DAESH created from the Arabic name of the organization. The organization pledge allegiance to $\mathrm{AQ}$ and participated in its fight with Western forces in Iraq War (2003-2011) but in 2013 broke alliance and started fight down AQ. 
a strategy of action, a goal and tactics adjusted to it - leaders of such groups calculate costs and benefits, assess the risk and their decisions are often rational, well thought out and fully informed (Bolechów, 2010, p. 23-46). A contemporary terrorist organisation has to function as a well-managed company. It needs efficient system of command, organisation of activities, a system of recruitment and training new members. It also requires a spokesman, skilful specialists in the media, public relations, information and propaganda. Also a well-organised logistics network as well as financing and communication systems are necessary for such organisations to function efficiently, especially when operating from the underground (Jaworski, 2006, p. 52-57).

According to the report Evolution of Jihadi Video (Intel Center, 2005), Palestinians and Chechens were the first ones to film military actions and partisan fighting. The leader of Chechen troops, Ibn al-Khattab (Thamir Saleh Abdullah) quickly realised that although successful attacks on Russian outposts weaken the enemy, they bring relatively small results. Due to an information blockade the Russian public did not know that Russian soldiers suffered defeat and that the government did not control the situation. Filming military activities also had another, equally important purpose - raising the morale of other fighters. Video recordings presenting successful missions and victories inspired and motivated militants to fight in very difficult and unfavourable conditions. Thus groups under the command of Ibn al-Khattab recorded everyday aspect of the unit: skirmishes with Russian soldiers, well-organised ambushes and war councils.

In 2000, the group released a 40-minute film entitled Russian Hell No. 1. The aim of this recording was to show that Chechen militants were successful, well trained and ruthless towards captured enemies. The film is an amateur production shot by random people who did not receive training on video-recording and probably had only a simple VHS camera. A cameraman, whose hands constantly shook and who did not have the frame under full control, poorly administered the zoom in/out feature. The film consists of several fragments and presents partisan combat, successful ambushes against Russian soldiers, destroying their equipment as well as killing and finishing off captives. The sound is of poor quality, thus instead of sounds of combat viewers can hear pieces of vocal music, the so-called nasheed, melodic, wistful songs about the beauty of combat and dying in the name of God (Allah), sung a cappella.

The idea was quickly copied by al-Qaeda ${ }^{2}$ who a couple months later produced a 2-hour film entitled The Destruction of the Destroyer USS Cole. It soon became the ambition of every major terrorist group to document their achievements. Due to the development of the Internet and technological advancement filming and making acts

2 Shortly before the $9 / 11$ attack. 
of terror public has never been so easy and cheap. In 2002 a journalist, Daniel Pearl, was killed in Pakistan by terrorists, who forced him to give a statement in which he condemn USA foreign policy. The statement and moment of death were filmed and initiated the barbarian way of dealing with hostages. Abu Musab Al-Zarqawi, the founder of jihadi organization, which later transformed itself into ISIS, used the strategy of shocking by cruelty. In May 2004, a masked man (probably Zarqawi) slashed the head of Nick Berg, an American citizen. The decapitation was filmed. The organization has carried out about ten similar executions. Making movies showing cruelty has become a steady terrorists' strategy. This trend has continued for several years, although a lot has changed since the first cassettes with speeches delivered by the then leader of al-Qaeda, Osama bin Laden, or the film recorded in 2004 presenting a masked $\operatorname{man}^{3}$ decapitating Nicholas (Nick) Berg were brought out into the open. Amateur productions shot with a shaky hand, in random places, full of blurred shots and weak sound have been replaced by films refined in every detail, shot in outdoor locations, professionally edited video and audio, directed according to a script. $\mathrm{Al}$ Furqan Media, which produce films for ISIS, specialises in such productions.

The empirical system of reference of this article is the activity of ISIS and AQAP, although these are not the only organisations which use media and the so-called new media. An interesting example is the media wing of Lebanese Hezbollah, TV station and portal al-Manar (the Beacon), which for years has propagated controversial views and promoted behaviours threatening national security (calls for attacking Israel and the USA, encouraging suicide attacks). Although the station also shows news from other spheres of life, the actions of the Party of God are always presented in a positive way. The portal offers a lot of downloadable material and mobile apps, also in English and French. As demonstrated by the example above, the Internet is currently the most popular ground used by terrorist organisations for publishing, communicating and exchanging information.

Currently, teams of specialists from groups such as al-Hayat Media Center (associated with ISIS), al-Malahem Media (associated with AQAP), as-Sahab and alFajr Media Center (media wing of al-Qaeda) and al-Furqan Instytute (ISIS) prepare professionally informative and propaganda-like campaigns, produce documentaries, online magazines and directed executions ${ }^{4}$. They prepare various materials and publications.

3 Most likely it was Abu Musab Al-Zarqawi.

4 All magazines and videos discussed in the article are in the author's archive. 


\section{What is Being Said?}

A special term has been coined for the film productions created by fundamentalist terrorist group - jihadi video production. In 2005, a typology of these types of films was created (Intel Center, 2005, p. 6-7):

They include the following:

1. videos presenting an organisation, its goal and leaders (produced videos),

2. videos showing the operation of an organisation - skirmishes, attacks, fighting, but also integration with civilian population, helping and supporting them (operational videos),

3. videos showing hostages (hostage videos) - as confirmation of kidnapping, informing viewers about the demands of a group or presenting an execution of hostages,

4. videos showing statements (statement videos) related to alliances, changes in the leadership, plans of an organisation, claiming responsibility for an attack, declarations of committing more acts of terror,

5. videos which commemorate a dead, important leader/member of an organisation (tribute videos),

6. videos showing elements of militant training (internal training videos); produced either for an organisation's own use or for promotional purposes,

7. videos with instructions/tips (instructional videos) which mainly present ways of making improvised explosives ${ }^{5}$ or instructing how to handle a firearm (dismantling, and cleaning a weapon, shooting positions).

Productions of terrorist organisations' meia outlets are not only presented as videos. Current online publications also include magazines, books, manuals, films and music. A considerable part of these publications contain instructional and propaganda-like materials for future fighters. Terrorist organisations extend the scale of operation and recruit fighters from outside of the area of conflict, frequently from the broadly understood West, also those who do not speak Middle Eastern languages. Thus more and more materials on the Web are published in English (mainly), French, German and Russian. These publications are prepared extra professionally because terrorist groups, especially those with substantial funds, have teams of media specialists at their disposal, often even separate divisions responsible for media communication.

The first issue of magazine entitled Inspire was published by AQAP in 2010. Although it was not the first English-language jihadi magazine (Hegghammer,

5 IED - Improvised Explosive Device - a homemade explosive device intended to be used in a terrorist attack or a diversion. 
2010), its high quality, easy access and publicity accompanying every issue made it regarded first well-known, easily accessible magazine published by terrorist. Between 2010-2016, 16 issues of the periodical have been published. AQAP, famous for very well-functioning media base, published also Șadā al-Malāhim (Echo of the Epics) magazine and frequently uploads manifests and short videos on the Web. Inspire is an instructional and propaganda magazine which features interviews with terrorist group leaders, commanders, Muslim clerics, and contains stories of mujahids from various parts of the world, also Europe, it documents the organisation's achievements, describes in detail acts of terror committed by the organisation, and presents reportages from training camps. However, it mainly provides professional instructions on how to make various kinds of explosives and other ways of killing a civilian population in large numbers. The authors of the texts explicitly call for committing acts of terror on the territories of EU and the USA.

The purpose of Inspire has been delineated in the first issue - to turn a Muslim into a mujahid fighter ${ }^{6}$. The authors, aware that there are millions of Muslims all over the World whose mother tongue (or official language of their country of residence) is English, prepared grounds for exchanging information, a place people will address the issues related to $\mathrm{ummah}^{7}$ and jihad ${ }^{8}$ which is an indispensable asset into the rebirth of the Caliphate (Inspire, 2010, p. 2). The above assurances does not differ from declarations included in publications promoting Islam. However, on one of the pages of the fifth issue of the magazine information about the failed terrorist attack from 2009 by Umar Farouk Abdulmutallab who boarded an American plane carrying an improvised explosive device which ultimately did not explode. The would-be suicide bomber was described as a hero and his action was praised. The authors asked the readers to pray for this brave fighter and encouraged all Muslims who take issue with the presence of the Crusaders (citizens of the broadly understood West) in the Arabian Peninsula to attack embassies. Soldiers working for Western armies or "puppet governments" in the Middle East are encouraged to commit acts of terror just like Nidal Hasan did, using all available means, in the name and for the glory of Allah (the one and only God) so that Islam would dominate the world (Inspire, 2010, p. 5).

6 Mujahid - someone who struggles for the sake of Islam, person engaged in jihad. Currently this term is used when referring to religiously-inspired Muslim fighters who participate in guerilla fights or fight against governments which they do not accept.

7 Ummah - the community of believers, all people following Islam.

8 Jihad - a term referring to all efforts made towards spreading and strengthening Islam: mainly through internal struggle and spiritual development of the follower or converting infidels. Radical terrorist groups define jihad as an armed struggle against infidels. In the media this term is frequently but not accurately translated as „holy war”. 
The article includes threats against Americans who support governments responsible for the deaths of Muslims. The anonymous author claims that an army of people who do not care about their own lives will soon come to murder, spread fear and it will be impossible to stop them (Inspire, 2010, p. 5). The above issue also features an interview with the then leader of AQAP, articles about outlooks on life, a selection of news from the world, sections related to caricatures of Muhammad and an appeal of bloody revenge for those insults. Due to these types of articles Inspire does not only promote Islam, but armed jihad as well. It is a source of information and inspiration for potential lone wolves who can familiarize themselves with the methods of killing civilian population in the section entitled Open Source Jihad, which gives direct instructions how to prepare terrorist attack

Equally glaring but not as a frequently discussed example is the so-called Cosmopolitan for female jihadists. Al-Shamikha magazine was issued by the media group al-Fajr Media Center associated with al-Qaeda. The only available issue of this magazine (in Arabic) appeared online and in print in 2011. A version in English has never been published, although AQAP issued in that time, for example, the Inspire magazine in English.

At first glance, Al-Shamikha looks like any other women's magazine or, to be more precise, a periodical addressed to stereotypical readers of women's press. The magazine is designed with a pastel colour scheme, the texts are ornamented with decorative margins, fonts and many illustrations. The pink colour does not match the barrel of a sub-machine gun on the cover and the title Meeting with a mujahid's wife. Moreover, in the table of contents (Al-Shamikha, 2011, p. 2) we can also find a position of the following type: Marrying a jihadist, Sharia law that applies to you, A female martyr and a supplement Your house is your kingdom with an advice section. Modern in form and conservative in content, the periodical is not so much a guide addressed to female readers as a certain kind of manifestation of the views of the organisation which publishes it. Interviews, essays, pieces of advice included in - as stated in the subtitle of the magazine - a magazine for Islamic female jihadists, clearly show the kind of role a woman in a militant state should play. The cover story, Meeting with a mujahid's wife, is a long and moving interview with a widow of a fighter who died in battle. The heroine of the interview in a diffused and emotional manner tells about a dream which possesses her life. Umm Muhanad, as this is the name under which the widow appears, emphasises from the moment when she learned that mujahideen fight in Chechnya and Bosnia that she wanted to become a wife of one of them (AlShamikha, 2011, p. 9-12). She speaks with great detail about the joy of being a life companion to a fighter and about the importance of her role. She expresses the hope that her children will share the fate of their father while she will support them in their 
steps to becoming mujahideen and then shahids. When asked whether a woman is an obstacle to a fighter or helps in fulfilling his mission, she answers that a wife who is supportive and who shares her husband's point of view is very important for a true mujahid. The interview ends with a message to other women who also have lost their husbands - mujahideen that they should remember that a great blessing has befallen upon them.

It is uncertain whether the heroine of the interview exists or not, she is probably some form of a model character. This is how the authors of the publication would like to see women in the society under their rule. The topic of the advantages of marrying a mujahid also appears in the article Marrying a jihadist. Such relationships, says the author (female author?), is not only about life, but a joy which leads straight to Paradise. Marriage with a fighter, concluded with the blessing of Allah, is a pleasure of giving and a delight of obedience (Al-Shamikha, 2011, p. 18). Life of a model dignified or majestic woman, as this is how the Arabic title of the magazine can be translated, is not only limited to lofty glorious matters. In the section entitled Your house is your kingdom the readers can find a number of tips related to lifestyle and of carrying one's appearance. The authors write that $90 \%$ of a woman's beauty is her skin, warning against the harmful influence of the sun which damages it irreversibly (Al-Shamikha, 2011, p. 23-30) and concludes: out of concern for your beauty it is best to stay at home. The following page includes a recipe for a honey mask and a promise that the next issue will feature a recipe for a peel-off mask - in sha Allah. However, the second issue was never released.

\section{In Which Channel?}

Informational and propaganda materials are mainly published online and, due to social networking sites, spread quickly duplicated in millions of copies. Terrorist organisations have official social network accounts on Facebook or Twitter, publish propaganda and informational content, respond to questions on portals like ask.fm. However, their strength does not lie in their official accounts but in the hundreds of thousands of profiles of their supporters and sympathisers who exchange information, publish visual materials, establish friendships with potential recruits, and communicate with each other. They frequently use encrypted apps and apply the Internet to the purposes of their organisations in a very professional manner. An eminent journalist and a Middle East expert summarises the strength of ISIS media with the following words: "Half of Jihad is Media" is one slogan posted on a jihadist website, which, taken broadly, is wholly correct. The ideas, actions, and aims of fundamentalist Sunni jihadists are broadcast daily through satellite television stations, YouTube, Twitter, and 
Facebook. As long as such powerful means of propagandizing exist, groups similar to al-Qaeda will never go short of money or recruits (Cockburn, 2014, p. 168).

\section{To Whom?}

There is no propaganda message addressed to everyone. Similarly, the media messages created by ISIS and other terrorist organisations differ depending on the target group. Several target groups can be distinguished:

1. potential fighters; videos produced for them show fighting, brotherhood of arms, modern equipment and man's adventure. They are told about their religious duty to participate in armed jihad.

2. sympathisers and activists; although they will not take part in fighting directly, their social networking accounts and contact networks will serve as a speaking tube for the propaganda. Due to thousands of radical followers of ISIS and al-Qaeda, videos or music spreads throughout the Internet with lightning speed.

3. potential sponsors and decision-makers; The success of terrorist organisations depends, on the one hand, on the money of radical sympathisers from the Arabian Peninsula and, on the other hand, regional powers which wage a proxy war in Syria and Iraq.

4. local enemies of the organisations; ISIS shows brutality to spread fear among Iraqis and Syrians, fuel hatred between Sunni and Shia Muslims, decrease morale of the enemy's armies, break the resistance of civilians, conquer new territories (which will be ruled by terror) and look for support among the undecided.

5. radicals living in the West; the propaganda of ISIS, al-Qaeda and AQAP skillfully reinforces their radical views, inspires to carry out acts of terror and help those who organise them.

6. Western societies; in materials of terrorist organisations they are referred to as infidels, Crusaders or Zionists. The aim of those publications is to spread terror in Western societies, maintain the atmosphere of fear and uncertainty, deepening radical attitudes and hostility.

It should be noted that media messages of terrorist organisations fit perfectly the media's demand for brutality and tragedy which sell much better than good news. At a time when the public wants shock, horror and blood, ISIS media wings deliver exactly the needed materials which are prepared professionally. They do not require high financial expanses, editing or substantial processing and are ready to be included in the evening prime time news. Thus terrorists can influence the way in which they are presented in the media. 


\section{With What Effect?}

In the 1980s, fighters arrived to join the holy war in Afghanistan (the Soviet-Afghan War), in the 90's to Bosnia and Chechnya and finally at the beginning of the $21^{\text {st }}$ Century to Iraq (2003), Somalia (2006) and Afghanistan (2001). Volunteers identifying themselves with various forms of armed jihad who fight and die in conflicts and wars for many decades are referred to using the acronym FTF (foreign terrorist fighters). Currently, terrorist organisations such as the so-called Islamic State, alQaeda or al-Qaeda in the Arabian Peninsula reach out to fighters from the West who undergo radicalisation by accessing publications in English. ${ }^{9}$ These include strictly propaganda materials as well as manuals and guides which can be divided into two categories - publications which are created for volunteers ${ }^{10}$ who are preparing to come to the Middle East and publications for radicals who are spreading terror in the infidels' countries.

Out of 70,000 mujahids fighting for the so-called Islamic State, foreign volunteers constitute 40\% (Schmid, Tinnes, 2015, p. 7-8) and the majority of them are from the Middle East ${ }^{11}$. Currently, it is estimated that around 30,000 fighters from more than 100 countries (Schmid, 2015, p.1) have joined the ranks of ISIS mujahids - around 6,000 comes from Europe. Although volunteers have also joined the al-Nusra Front, $80 \%$ of the newcomers fight under the aegis of the Caliphate. It should be stressed that, although decisions to leave Europe and join a terrorist organisation is a result of various circumstances and motives, social networking sites and recruitment propaganda of terrorist organisations play an important role (self-reference) in this matter.

The publications of terrorist organisations are consulted by so-called lone wolves. The 2015 San Bernardino terrorist attack was carried out on the December, 2 by a Pakistani couple (an American male of Pakistani descent and a Pakistani female) who had no criminal record and weren't on the Terrorist Screening Database (TSDB) list. During an office Christmas party for employees of centre for persons with disabilities, which was attended by almost 100 people, Syed Rizwan Farook (b. 1987) with his wife Tashfeen Malik (b. 1986) opened fire and killed 14 people, injured 21 and fled the scene. They left behind an IED (constructed according to the instructions provided in the al-Qaeda's Inspire magazine no. 1/2010) hidden in a backpack which was supposed to explode when the emergency personnel responding to the event would arrive. The device failed to explode and was disarmed by a bomb squad. The couple

\footnotetext{
9 The magazines of these organisations are also available in French, German and Russian.

10 For example Hijra to the Islamic State (2015) [n.p.].

11 The largest numbers from Saudi Arabia, Tunisia, Libya and Jemen.
} 
had no ties with any terrorist organisations, was not a part of any terrorist cell and had become radicalised over the past several years prior to the attack (but before the emergence of ISIS as a 'state').

\section{Conclusions}

Firstly, the Internet is a speaking tube for propaganda, a place for recruitment of future fighters and, most importantly, a ground allowing rapid dissemination of content and information which are important to terrorist organisations. Terrorist groups have special departments managing media and communication strategy of the organisation. They publish materials of very high quality, make efficient use of modern technologies and social media.

Secondly, the activities of terrorist organisations, seemingly chaotic and random, are in fact a thought-through method of operation. Terrorists' methods, means and strategy are constantly evolving toward higher efficiency and effectiveness.

Moreover, terrorism is an effective use of violence and fear, achieving political goals by skilful manipulation of the use of force (real or potential) and the impression evoked by it (Białek, 2005, 33).

Thirdly, he propaganda of terrorist organisations skilfully exerts influence on minds and hearts of young radicals, fuels their hatred and provides them avenues for action. It speaks their language, adjusts the level of the messages to the intellectual capabilities of the receivers and chooses arguments very carefully. Furthermore, the spectacularism of operation and low detectability causes Salafi organisations to inspire lone wolves to carry out acts of terror. The Internet is an ideal ground for uploading propaganda materials and instructions.

\section{References:}

Bolechów, B. (2010). Terroryzm: aktorzy, statyści, widownie. Warszawa: Wydawnictwo Naukowe PWN.

Białek, T. (2005). Terroryzm: manipulacja strachem. Warszawa: Wydawnictwo Studio EMKA.

Cockburn, P. (2014). Państwo Islamskie, Warszawa: Wydawnictwo Naukowe PWN.

Goban-Klas, T. (2009). Media i terroryści. Czy zastraszq nas na śmierc? Kraków: Wydawnictwo Uniwersytetu Jagiellońskiego

Evolution of Jihadi Video (2005). Intel Center. Retrieved from https://intelcenter.com/EJV-PUBv1-0.pdf.

Hegghammer, T. (2010). "Un-Inspired”. Jihadica. Retrieved from: http://www.jihadica.com/ un-inspired/. 
Holtmann, P. (2012). „Virtual Jihad: A Real Danger”. In R. Lohlker, New Approaches to the Analysis of Jihadism: Online and Offline (pp. 9-14). Goettingen: V\&r Unipress.

Jaworski, M. (2006). „Ekonomia a terroryzm”. In K. Liedel (Ed.), Terrozyzm. Anatomia zjawiska (pp. 21-66). Warszawa: Wydawnictwo Scholar

"Letter from the editor" (2010). Inspire, 1p. 2. Retrieved from https://azelin.files.wordpress. com/2010/06/aqap-inspire-magazine-volume-1-uncorrupted.pdf.

Liedel, K. (Ed.) (2006). Terrozyzm. Anatomia zjawiska. Warszawa: Wydawnictwo Scholar.

"Marrying a jihadist" (2011). Al-Shamikha, 1, p. 18. Retrieved from https://www.archive.org/ stream/AlshamikhaMagazine/AlshamikhaM\#page/n17/mode/2up.

"Meeting with a mujahid's wife" (2011). Al-Shamikha, 1, p. 9-12. Retrieved from https://www. archive.org/stream/AlshamikhaMagazine/AlshamikhaM\#page/n7/mode/2up.

Pisarek, W. (2008). Wstęp do nauki o komunikowaniu, Warszawa: Wydawnictwa Akademickie i Profesjonalne.

Schmid, A.P., \& Tinnes, J. (2015). "Foreign (Terrorist) Fighters with IS: A European Perspective", The International Centre for Counter-Terrorism - The Hague, 6(8), pp. 1-69. DOI: http:// dx.doi.org/10.19165/2015.1.08.

Schmid, A.P. (2015). "Foreign (Terrorist) Fighter Estimates: Conceptual and Data Issues “, The International Centre for Counter-Terrorism - The Hague, 6(4), pp. 1-21, Retrieved from https:// www.icct.nl/wp-content/uploads/2015/10/ICCT-Schmid-Foreign-Terrorist-Fighter-EstimatesConceptual-and-Data-Issues-October20152.pdf.

"The Operation Of 'Umar Al-Faruq Al-Nigiri In Response To The American Aggression On Yemen” (2010). Inspire, 1, p. 5. Retrieved from https://azelin.files.wordpress.com/2010/06/ aqap-inspire-magazine-volume-1-uncorrupted.pdf.

"Your house is your kingdom" (2011). Al-Shamikha, 1, p. 23-30. Retrieved from https://www. archive.org/stream/AlshamikhaMagazine/AlshamikhaM\#page/n21/mode/2up.

\section{Author}

Dr Karolina Wojtasik

University of Silesia, Institute of Sociology. Contact details: ul. Bankowa 11, 40-007 Katowice, Poland; e-mail: karolina.wojtasik@us.edu.pl. 